\title{
Impact of Flavonoids against Woolly Apple Aphid, Eriosoma lanigerum (Hausmann) and Its Sole Parasitoid, Aphelinus mali (Hald.)
}

\author{
Mazen Ateyyat (Corresponding author) \\ Faculty of Agricultural Technology, Al-Balqa' Applied University \\ PO box 19117, Al-Salt, Jordan \\ E-mail: m_ateyyat@yahoo.com \\ Saeid Abu-Romman \\ Faculty of Agricultural Technology, Al-Balqa' Applied University \\ PO box 19117, Al-Salt, Jordan \\ Mohmmad Abu-Darwish \\ Ash-Shoubak University College, Al-Balqa' Applied University \\ PO box 19117, Al-Salt, Jordan \\ Ihab Ghabeish \\ Al-Salt University College, Al-Balqa' Applied University \\ PO box 19117, Al-Salt, Jordan
}

Received: June 16, 2011

Accepted: July 12, $2011 \quad$ Online Published: December 21, 2011

doi:10.5539/jas.v4n2p227

URL: http://dx.doi.org/10.5539/jas.v4n2p227

The research is financed by Scientific Research Fund, Ministry of Higher Education, Jordan.

\begin{abstract}
Cut-shoot bioassay test was used to study the significance of three flavonoids as aphicides against the woolly apple aphid (WAA), Eriosoma lanigerum (Hausmann). The used flavonoids were two flavanols that are quercetin dehydrate and rutin hydrate, but rutin hydrate is a glycoside of quercetin dehydrate. In addition to one flavanone that was naringine. These flavonoids were used at three concentrations; $100 \mathrm{ppm}, 1000 \mathrm{ppm}$ and $10,000 \mathrm{ppm}$. Results showed that the three tested flavonoids were active as aphicides against the target species and that mortality to nymphs was higher than that obtained against apterous adults. Increasing the concentration of the flavonoids resulted in a remarkable increase in nymphs mortality. However, rutin hydrate is more toxic to WAA than quercetin dehydrate and naringin.

The three flavonoids had slight effect on the sole parasitoid of WAA, Aphelinus mali compared with effect caused by imodacloprid insecticide. Quercetin dehydrate, rutin hydrate and naringine can be used as botanical insecticides and incorporated into integrated management programs of the aphid.
\end{abstract}

Keywords: Bioassay, Botanical insecticides, Flavonoids, Woolly apple aphid, Aphelinus mali

\section{Introduction}

Flavonoids which are derived from flavanone, include more than 4000 chemical structures and are widely distributed in the plant kingdom, they are a group of polyphenolic phytochemicals that include flavones, isoflavones, (iso)flavanones, catechins, and chalcones, among other chemicals. They occur in relatively high concentrations in fruits, vegetables, nuts and grains, and in various herbs and spices. Examples are the flavanones naringenin and sakuranetin in rice (Rakwal et al., 1996; Kodama, 1996), the isoflavonoids kievitone and 
phaseollin in beans (Goossens, 1987; Stossel \& Magnolato, 1983; Liu et al., 1995) and the catechins epicatechin and epigallocatechin in green tea (Ishikawa et al., 1997). Catechins and flavan-3,4-diols can polymerize to polyflavonoids called condensed tannins. Flavonoles are the most abundant flavonoids. The concentration of quercetin, the most important flavonole, is $<10 \mathrm{mg} / \mathrm{kg}$ in the edible parts of most vegetables (Hertog et al., 1992). Exceptions include onions, kale, French beans, apples, cherries, and broccoli, where concentrations may amount to 30 to $490 \mathrm{mg} / \mathrm{kg}$ (Hertog et al., 1992). Like most other flavonoids, quercetin in plant tissue is found mainly in its glycosidic form, e.g., as rutin.

Flavonoids are known to have widely diverse beneficial biological effects, such as anti-inflammatory (Middleton, 1998), antioxidant (Pietta, 2000), antiviral (Jassim \& Naji, 2003), and anticancer effects (Adlercreutz, 2002; Rietveld \& Wiseman, 2003). Simmonds (2001, 2003) studied the bioactivity of different flavonoids and confirmed that these compounds could modulate the feeding and oviposition behavior of insects. Also, flavonoids inhibited the mycelial growth of a crop pathogen, Verticillium albo-atrum (Picman, 1995).

Woolly apple aphid (WAA), Eriosoma lanigerum (Hausmann) (Homoptera: Aphididae) is an important insect that infests apple orchards worldwide (Ateyyat \& Al-Antary, 2009), and is considered to be critical to the economics of the apple industry (Bus et al., 2007). WAA infests both the shoot and root parts of the apple tree (Gurney, 1926; Lloyd, 1961). Its infestation reduces vegetative growth and hence production capacity (Brown \& Schmitt 1990; Brown et al., 1995). The most important natural enemy for WAA is Aphelinus mali (Hald) (Hymenoptera: Aphelinidae), which parasitizes the aerial population of WAA (Mols \& Boers, 1998).

The purpose of this study is to investigate the aphicidal effect of some flavonoids against woolly apple aphid (WAA), Eriosoma lanigerum (Hausmann) as botanical bio-insecticide to be used as part of integrated pest management (IPM) program for this pest that attacks apple in Jordan and many countries in the world.

\section{Material and methods}

\subsection{Favonoids}

Naringin ( $\geq 90 \%$, from citrus fruit, crystalline), quercetin dihydrate ( $\geq 98 \%$, HPLC, powder) and rutin hydrate ( $\geq 95 \%$, HPLC, powder) were purchased from Sigma (USA). Three concentrations (100, 1000, and 10000 ppm) of each dry extract were prepared by dissolving the dry extract in $0.01(\mathrm{v} / \mathrm{v})$ dimethyl sulfoxide (DMSO) solution.

\subsection{Control treatments}

Two control treatments were used in each experiment. The negative control was DMSO that was dissolved in water to form a concentration of $0.01(\mathrm{v} / \mathrm{v})$, in which extracts were dissolved. Imidacloprid (Confidor ${ }^{\circledR}$ 200SC, Bayer Crop Science, Jordan) insecticide was used as positive control treatment at the recommended field application rate of $0.25 \mathrm{~mL} \mathrm{~L}^{-1}$. DMSO at concentration of $0.01(\mathrm{v} / \mathrm{v})$ showed no significant mortality effect against peach trunk aphid (Ateyyat \& Abu-Darwish, 2009) compared with water and for this; it was used as negative control.

\subsection{Insect}

The insecticidal activity of the above mentioned extracts was tested against the woolly apple aphid (WAA). Insects were collected from the apple fruits orchard in Ash-Shoubak University College in 2006. A colony of aphids was established from a single apterous virginoparae adult in a glasshouse $\left(\right.$ at $\left.25 \pm 5^{\circ} \mathrm{C}\right)$ in Ash-Shoubak University College on 2-year old seedlings of apple, Malus domestica Borkhausen. Offspring were used to infest more seedlings of apple. Subsequent colonies were reared in a glasshouse at $25 \pm 5^{\circ} \mathrm{C}$ and in a cycle of $16 \mathrm{~h}$ light, $8 \mathrm{~h}$ dark (L 16:D 8), inside fine net cages to protect them from parasites and predators.

\subsection{Parasitoid}

The insecticidal activity of the above mentioned extracts was also tested against Aphelinus mali, the sole parasitoid of WAA. Apple twigs infested with E. lanigerum which had been parasitized by A. mali were collected during August and September from an organic orchard in Ash-Shoubak. The twigs were placed in a rearing cage $(2 \times 1 \times 1 \mathrm{~m})$ covered with organdy cloth. The cages for parasitoid rearing were maintained in a glasshouse in at $25 \pm 5^{\circ} \mathrm{C}$ and in a cycle of $16 \mathrm{~h}$ light, $8 \mathrm{~h}$ dark (L16:D8).

\subsection{Bioassays to WAA and Aphelinus mali}

A cut-shoot bioassay, adapted from the method developed by Desprez-Loustau (1990), was used. Colonies of WAA were established on 10-cm length excised twigs under laboratory conditions (with temperature ranging from 20 to $25^{\circ} \mathrm{C}$ and relative humidity of 45 to $70 \%$ ) from adult apterous virginoparae collected from the greenhouse. From the laboratory colonies, about 20 apterous parthenogenetic adults of WAA were taken to be 
placed on a damaged portion of an excised twig confined within a sleeve cage. The twigs with caged aphids were placed in plastic vials half-filled with water and placed on a test-tube rack. After one day, any new born nymphs as well as adults failing to settle on the excised twigs were removed.

The excised twigs with aphids attached to them were dipped in the required solution for about 10 seconds. Five replicates for each concentration were used. Observations of mortality were carried out after $24 \mathrm{~h}$ and $72 \mathrm{~h}$, at the same time daily, using a magnifying lens $(\times 4)$. Adults of WAA that failed to settle on the excised twigs were considered as dead. The number of dead aphids and those failed to settle on each twig was counted along with the numbers left in the plastic vial attached to that plant. The percentage of mortality was calculated by taking the numbers of dead adults and those failed to settle on the twig, as a percentage of the total number of aphids before starting the tests. The experiment was repeated three times.

The toxicity of the three flavonoids were tested against the WAA parasitoid by dipping a 10-cm length excised twigs with mummified aphids attached to them in the solution of each flavonoid at the highest concentration (10000 ppm) for about 10 seconds. Then the twigs were kept under laboratory conditions (with temperature ranging from 20 to $25^{\circ} \mathrm{C}$ and relative humidity of 45 to $70 \%$ ). Five replicates for each flavonoid were used. The number of emerged adult parasitoids was counted after 12 days post treatment.

\subsection{Statistical analysis}

Arcsine-transformed percentage data were subjected to a one-way ANOVA, followed by a Least Significant Differences test at $95 \%$ confidence level (SAS Institute, 1995). Also, TableCurve program (Jandel Scientific) was used to predict the $\mathrm{LC}_{50}$ of each flavonoid.

\section{Results}

\subsection{Nymphs}

Nymphs of WAA showed to be significantly affected by the exposure to the tested flavonoids at three concentrations used (Table 1). At a concentration of 10,000 ppm, the three tested flavonoids; quercetin dihydrate, naringin and rutin hydrate showed significant mortality effect similar to that obtained by the positive control, imidacloprid after $24 \mathrm{~h}(\mathrm{~F}=106.31 ; \mathrm{df}=4,10 ; \mathrm{P}<0.001)$ and $72 \mathrm{~h}(\mathrm{~F}=58.56 ; \mathrm{df}=4,10 ; \mathrm{P}<0.001)$ of treatment. None of the tested flavonoids showed aphicidal activity against nymphs of WAA as that obtained by the imidacloprid activity after treating nymphs at a concentration of $1000 \mathrm{ppm}$ after $24 \mathrm{~h}(\mathrm{~F}=119.86 ; \mathrm{df}=4,10 ; \mathrm{P}<0.001)$ and $72 \mathrm{~h}$ $(\mathrm{F}=18.60 ; \mathrm{df}=4,10 ; \mathrm{P}<0.001)$. The same scenario was obtained after treating nymphs at a concentration of 100 ppm (Table 2).

\subsection{Adults}

Quercetin dihydrate, naringin and rutin hydrate used at the three concentrations resulted in a significant reduction of apterous adults of WAA (Table 2). Treating apterous adults with quercetin dihydrate, naringin and rutin hydrate at a concentration of $10,000 \mathrm{ppm}$, resulted in a significant mortality to the insects similar to that obtained by imidacloprid after $72 \mathrm{~h}(\mathrm{~F}=41.17 ; \mathrm{df}=4,10 ; \mathrm{P}<0.001)$ (Table 2). When the flavonoids used at a concentration of $1000 \mathrm{ppm}$, only rutin hydrate showed significantly the same mortality effect as that obtained by imidacloprid after $72 \mathrm{~h}(\mathrm{~F}=18.6 ; \mathrm{df}=4,10 ; \mathrm{P}<0.001)$ (Table 2$)$.

\subsection{Concentration vs mortality}

A remarkable increase in the mortalaity of nymphs was obtained by increasing the concentration of quercetin dihydrate, naringin and rutin hydrate after $24 \mathrm{~h}$ of treatment (Figs. 1,2,3). On the other hand, mortality to apterous adults did not increase remarkably by increasing the concentration of the tested flavonoids after $24 \mathrm{~h}$ (Figs. 4,5,6). The predicted $\mathrm{LC}_{90}$ of quercetin dehydrate, rutin hydrate and naringin against WAA nymphs is 10807, 9292 and 11110 ppm, respectively (Figs. 1,2,3) The predicted $\mathrm{LC}_{90}$ of quercetin dehydrate, rutin hydrate and naringin against apterous adults of WAA is 20808, 19998 and $50601 \mathrm{ppm}$, respectively.

\subsection{Toxicity to Aphelinus mali}

Quercetin dihydrate, rutin hydrate and naringin showed slight effect on Aphelinus mali compared with the effect caused by imidacloprid that prevented more than $88 \%$ of adults of the parasitoid to emerge from the mummified aphids (Fig. 7).

\section{Discussion}

Control of woolly apple aphid poses serious problems as this insect attacks both root and shoot systems of apples worldwide. The greatest obstacle in the massive use of pesticides is their loss of efficacy caused by resistance development in insects (Georghiou and Mellon, 1983; Denholm et al., 1999). It is necessary to search for 
alternative strategies in pest control in order to circumvent existing resistance and minimize the danger of new resistance. Also, environmental aspects, like persistence of active compounds in soil, ground water and lakes, as well as effects on non-targets, have to be considered more consciously. The so-called "botanicals" (active substances or mixtures of substances) extracted from plants are desirable preparations that exhibit new modes of action and impair processes that are rather specific for the pests to be combated. Völlinger and Schmutterer (2002) elucidated that application of mixtures of active substances slows resistance development considerably.

Three flavonoids were used in this study. These are quercetin dehydrate, rutin hydrate and naringin. The first two are flavanols. But rutin hydrate is a glycoside of quercetin dehydrates. Naringine is a flavanone. The present study showed that the predicted $\mathrm{LC}_{90}$ for using rutin hydrate is lower than that obtained for both quercetin dehydrate and naringin, which means that this flavonoid is more toxic to WAA than the other tested flavonoids. All tested flavonoids were more toxic to nymphs of WAA than to apterous adults.

A large number of plant-derived substances posses physiological and behavioural activities against insect pests and may provide new sources of natural pesticides. Natural products have shown that it is possible to produce a great range of biological activities, including toxicity, repellent action, anti-feedant and growth regulation properties (Huang \& Ho, 1998; Chiam et al., 1999).

Flavonoids have a key role in stress response mechanisms in plants. The adaptive role of flavonoids in plant defense against bacterial, fungal and viral diseases as well as insects is beginning to gain importance in our understanding of plant defense. They act as anti-oxidants or as enzyme inhibitors, are involved in photosynthesis and cellular energy transfer processes, and may serve as precursors of toxic substances (Harborne \& Mabry 1982; Mcclure, 1986).

In the present study, the three tested flavonoids were active as aphicides against the WAA and the obtained mortality to nymphs was higher than that obtained against apterous adults.

Most studies on the use of flavonoids as natural insecticides were concentrated on chewing larvae and/ or adults of lepidopteran, coleopteran and hymenopteran insects (Sosa et al., 2000; Simmonds, 2001, 2003; Upasani et al., 2003; Salnuke et al., 2005). Wood et al., $(1986,1990)$ studied the activity of flavonoids against nymphs of Triatoma infestans (Hemiptera: Reduviidae). However, this is the first study as far as the authors know that handles the toxicity of flavonoids against homopteran insects, particularly against the woolly apple aphid that represents an important insect of apple worldwide.

Sosa et al., (2000) investigated 20 flavonoids isolated from Argentina native plants and others, commercially purchased on T. molitor larvae growth, results indicated that quercetin, was the most effective growth inhibitor for T. molitor larvae.

Flavonoids from leaves of Annona squamosa (Kotkar et al., 2002) and Ricinus communis (Upasani et al., 2003) were found to arrest the population growth of adzuki bean weevil, $C$. chinensis $\mathrm{L}$ in green gram (Vigna radiata L.) during storage.

Flavonoids also showed an ovicidal effect on bruchid eggs as well as affecting the number and weight of the emerging adults as a function of concentration (Salnuke et al., 2005).

Salnuke et al., (2005) suggest that flavonoids can act as potential grain protectants via contact, oviposition deterrent and ovicidal action. Different flavonoids are found to alter moulting in insects, causing death (Stamp \& Yang, 1996). Most of the studied flavonoids either act as anti-estrogens or inhibit cytochrome P450 isozyme expression and activity (Mitchell, 1993; Tsyrlov et al., 1994).

Increasing the concentration of the flavonoids resulted in a remarkable increase in nymphs mortality. This result agree with finding of Salnuke et al., (2005), who found that flavonoids were toxic to adults and eggs of Callosobruchus chinensis (L.) depending on dose and exposure period.

The used flavonoids were active on nymphs more than adults and this could be attributed to the higher decrease in the glutathione $S$-transferases (GST) activity in nymphs over that happened in adults after exposure to flavonoids. Wood et al., (1986, 1990), proposed the decreased activity of GST as the main factor behind mortality of nymphs of Triatoma infestans (Hemiptera: Reduviidae). GSTs are a multifunctional group of active enzymes detoxification mechanisms (Wood et al., 1986; Wood et al., 1990).

In the present study, the three tested flavonoids showed to be of low toxicity to the parasitoid of WAA compared with the drastic effect caused by the use of imidacloprid insecticide against the mummified aphids that resulted in failure of emergence more than $88 \%$ of adult parasitoids. 
Nutritionists estimate the average intake of flavonoids by human, on normal diet, to be 1-2 g per day (De Vries, 1997). Also, flavonoids have very low toxicity to rats (Havsteen, 2002). The use of flavonoids can be a useful and sustainable strategy for the protection apple trees against woolly apple aphid as botanical insecticides in integrated pest management programs.

\section{Acknowledgement}

The project was funded by the Scientific Research Fund at Ministry of Higher Education of Jordan. The technical assistance by the agricultural engineer, Sana' Shgeirat, is gratefully acknowledged.

\section{References}

Adlercreutz, H. (2002). Phyto-oestrogens and cancer. Lancet Oncology, 3, 364-373. http://dx.doi.org/10.1016/S1470-2045(02)00777-5

Ateyyat, M. A., \& Abu-Darwish, M. S (2009). Insecticidal activity of different extracts of Rhamnus dispermus (Rhamnaceae) against peach trunk aphid, Pterochloroides persicae (Homoptera: Lachnidae). Spanish Journal of Agricultural Research, 7(1), 160-164.

Ateyyat, M., \& Al-Antary, T. (2009). Susceptibility of nine apple cultivars to woolly apple aphid, Eriosoma lanigerum (Homoptera: Aphididae) in Jordan. International Journal of Pest Management, 55(1), 79 - 84. http://dx.doi.org/10.1080/09670870802546164

Brown, M. W., \& Schmitt, J. J. (1990). Growth reduction in nonbearing apple trees by woolly apple aphids (Homoptera: Aphididae) on roots. Journal of Econmomic Entomology, 83, 1526-1530.

Brown, M. W., Schmitt, J. J., Ranger, S., \& Hogmire, H. W. (1995). Yield reduction in apple by edaphic woolly apple aphid (Homoptera: Aphididae) populations. Journal of Economic Entomology, 88, 127-133.

Bus, V. G. M., Changne, D., Bassett, H. C. M., Bowatte, D., Calenge, F., Celton, J..M., Durel, C..E., Malone, M.T., Patocchi, A, Ranatunga, A.C., Rikkerink, E. H..A., Tustin, D. S., Zhou, J., \& Gardiner, S. E. (2007). Genome mapping of three major resistance genes to woolly apple aphid (Eriosoma lanigerum Hausm.). Tree Genetics \& Genomes, 4, 223-236. http://dx.doi.org/10.1007/s11295-007-0103-3

Chiam, W. Y., Huang, Y., Chen, S. X., \& Ho, S. H. (1999). Toxic and antifeedant effects of allyldisulfide on Tribolium castaneum (Coleoptera: Tenebrionidae) and Sitophilus zeamais (Coleoptera: Curculionidae). Journal of Economic Entomology, 92, 239-245.

Denholm, I., Pickett, J. A., \& Devonshire, A. L. (1999). Insecticide resistance: from mechanisms to management. IACR-Rothamsted, Harpenden, UK.

De Vries, J. H., Janseen, P. L., Hollman, P. C., Van Staveren, W. A., \& Katan, M. B. (1997). Consumption of quercetin and kaempferol in free living subjects eating a variety of diets. Cancer Letters, 114, $141-144$. http://dx.doi.org/10.1016/S0304-3835(97)04645-4

Desprez-LouStau, M. L. (1990). Acut-shoot bioassay for assessment of Pinus pinaster susceptibility to Melampsora pinitorqua. European Journal Plant Pathology, 20, 386-391.

Georghiou, G. P. \& Mellon, R. B. (1983). Pesticide resistance in time and space. In: Pest resistance to pesticides (Georghiou G.P., Saito T., eds). Plenum, NY. pp 1-46.

Goossens, J. F., Stabel, A., \& Vendrig, J. C. (1987). Relationships between kievitone and phaseollin accumulation in different tissues of Phaseolus vulgaris in response to treatment with mercuric chloride, a fungal cell wall elicitor and abscisic acid. Physiological and Molecular Plant Pathology, 30, 1-12.

Gurney, W. B. (1926). The woolly aphis parasite (Aphelinus mali Hald.). The Agricultural Gazette of New South Wales, 37, 620-623.

Harborne, J. B., \& Mabry, T. J. (1982). The Flavonoids: Advances in Research, New York: Chapman and Hall.

Havsteen, B. H. (2002). The biochemistry and medical significance of flavonoids. Pharmacology and Therapeutics, 96, 66-202. http://dx.doi.org/10.1016/S0163-7258(02)00298-X

Hertog, M. G. L., Hollman, P. C. H., \& Katan, M. B. (1992). Content of potentially anticarcinogenic flavonoids of 28 vegetables and 9 fruit commonly consumed in The Netherlands. Journal of Agriculture and Food Chemistry, 40, 2379-2383. http://dx.doi.org/10.1021/jf00024a011

Huang, Y., \& Ho S. H. (1998). Toxicity and antifeedant activities of cinnamaldehyde against the grain storage insects, Tribolium castaneum (Herbst) and Sitophilus zeamais Motsch. Journal of Stored Products Research, 3, 11-17. http://dx.doi.org/10.1016/S0022-474X(97)00038-6 
Ishikawa, T., Suzukawa, M., Ito, T., Yoshida, H., Ayaori, M., Nishiwaki, M., Yonemura, A., Hara, Y., \& Nakamura, H. (1997). Effect of tea flavonoid supplementation on the susceptibility of low-density lipoprotein to oxidative modification. American Journal of Clinical Nutrition, 66, 261-266.

Jassim, S. A., \& Naji, M. A. (2003). Novel antiviral agents: a medicinal plant perspective. Journal of Applied Microbiology, 95, 412-427. http://dx.doi.org/10.1046/j.1365-2672.2003.02026.x

Kodama, O. (1996). Biochemical studies of rice phytoalexins. Mycotoxins, 42: 7-11.

Kotkar, E., Mendki, P. S., Sadan, S. V., Jha, S. R., \& Maheshwari, V. L. (2002). Antimicrobial and pesticidal activity of partially purified flavonoids of Annona squamosa. Pest Management Science, 58, 33-37. http://dx.doi.org/10.1002/ps.414.abs

Liu, L., Punja, Z. K., \& Rahe, J. E. (1995). Effect of Pythium spp. and glyphosate on phytoalexin production and exudation by bean (Phaseolus vulgaris L.) roots grown in different media. Physiological and Molecular Plant Pathology, 47, 391-405. http://dx.doi.org/10.1006/pmpp.1995.1067

Lloyd, N. C. (1961). The woolly apple aphid. The Agricultural Gazette of New South Wales, 72, 652-654.

Mcclure, J. W. (1986). Plant Flavonoids. In V. Cody, J. B. Harborne \& E. Middleton (Eds), Biology and Medicine: Biochemical, Pharmacological and Structure Activity Relationships. New York: Alan R. Liss.

Middleton, E.JR. (1998). Effect of plant flavonoids on immune and inflammatory cell function. Advances in Experimental Medicine and Biology, 439, 175-182.

Mitchell, M. J., Keogh, D. P., Crooks, J. R., \& Smith, S. L. (1993). Effects of Flavonoids and other allelochemicals on insect cytochrome P-450 dependant steroid hydroxylase activity. Insect Biochemistry and Molecular Biology, 23, 65-71. http://dx.doi.org/10.1016/0965-1748(93)90083-5

Picman, A. K., Schneider, E. F., \& Jaroslav, P. (1995). Effect of flavonoids on mycelial growth of Verticillium albo-atrum. Biochemical Systematics and Ecology, 23(7-8), 683-693. http://dx.doi.org/10.1016/0305-1978(95)00081-X

Pietta, P.G. (2000). Flavonoids as antioxidants. Journal of Natural Products, 63, 1035-1042. http://dx.doi.org/10.1021/np9904509

Rakwal, R. M., Hasegawa, M., \& Kodama, O. (1996). A methyltransferase for synthesis of the flavanone phytoalexin sakuranetin in rice leaves. Biochemical and Biophysical Research Communications, 222, 732-735. http://dx.doi.org/10.1006/bbrc.1996.0812

Rietveld, A., \& Wiseman, S. (2003). Antioxidant effects of tea: evidence from human clinical trials. Journal of Nutrition, 133, 3285-3292.

Salunke, B. K., Kotkar, H. M., Mendki, P. S., Upasani, S. M., \& Maheshwari, V. L. (2005). Efficacy of flavonoids in controlling Callosobruchus chinensis (L.) (Coleoptera: Bruchidae), a post-harvest pest of grain legumes. Crop Protection, 24, 888-893.

SAS Institute. (1995). JMP user's guide, ver 3.1, Cary, NC, USA

Simmonds, M. (2001). Importance of flavonoids in insect-plant interactions: feeding and oviposition. Photochemistry, 56, 245-252. http://dx.doi.org/10.1016/S0031-9422(00)00453-2

Simmonds, M. (2003). Flavonoids-insect interactions: recent advances in our knowledge. Photochemistry, 64, 21-30. http://dx.doi.org/10.1016/S0031-9422(03)00293-0

Sosa, M. E., Tonn, C. E., Guerreiro, E., \& Giordano, O. S. (2000). Bioactividad de flavonoides sobre larvas de Tenebrio monitor. Revista de la Sociedad Entomológica Argentina, 59, 179-184.

Stamp, N. E., \& Yang, Y. (1996). Response of insect herbivores to multiple allelochemicals under different thermal regimes. Ecology, 77, 1088-1102. http://dx.doi.org/10.2307/2265578

Stössel, P., \& Magnolato, D. (1983). Phytoalexins in Phaseolus vulgaris and Glycine max induced by chemical treatment, microbial contamination and fungal infection. Experientia, 39, 153-154.

Tsyrlov, I. B., Mikhailenko, V. M., \& Gelboin, H. V. (1994). Isozyme and species-specific susceptibility of cDNA-expressed CYPIA P450s to different flavonoids. Biochimica et Biophysica Acta, 1205, 325-335.

Upasani, S. M., Kotkar, H. M., Mendki, P. S., \& Maheshwari, V. L. (2003). Partial characterization and insecticidal properties of $R$. communis flavonoids. Pest Management Science, 59, 1349-1354.

Vollinger, M., \& Schmutterer, H. (2002). Development of resistance to azadirachtin and other neem ingredients. 
In: The neem tree (Schmutterer H., ed), 2nd edn. Neem Foundation, Mumbai, India. pp 598-606.

Wood, E., Casabe, N., Melgar, F., \& Zerba, E. (1986). Distribution and properties of glutathione-S-transferase from Triatoma infestans. Comparative Biochemistry and Physiology, 84: 607-618.

Wood, E., Melgar, S., \& Zerba, E. (1990). Inhibitors of the glutathione S-tranferases from Triatoma infestans. Anales de la Asociacion Quimica Argentina, 78, 251-260.

Table 1. Percentage mortality of nymphs of woolly apple aphid (WAA), Eriosoma lanigerum, subjected to different flavonoids at concentrations of 10,000 ppm, $1000 \mathrm{ppm}$ and $100 \mathrm{ppm}$

\begin{tabular}{|l|c|c|c|c|c|c|}
\hline \multirow{2}{*}{ Flavonoid } & \multicolumn{6}{|c|}{ Percentage of WAA nymphs mortality \pm SE } \\
\cline { 2 - 7 } & \multicolumn{2}{|c|}{$\mathbf{1 0 , 0 0 0} \mathbf{~ p p m}$} & \multicolumn{1}{c|}{$\mathbf{1 0 0 0} \mathbf{~ p p m}$} & \multicolumn{2}{c|}{$\mathbf{1 0 0} \mathbf{~ p p m}$} \\
\cline { 2 - 7 } & $\underline{\mathbf{2 4} \mathbf{h}}$ & $\underline{\mathbf{7 2} \mathbf{~ h}}$ & $\underline{\mathbf{2 4} \mathbf{~ h}}$ & $\underline{\mathbf{7 2}} \mathbf{~ h}$ & $\underline{\mathbf{2 4} \mathbf{~ h}}$ & $\underline{\mathbf{7 2} \mathbf{~ h}}$ \\
\hline Quercetin dihydrate & $85.00^{\mathrm{b}} \pm 2.9$ & $93.3^{\mathrm{a}} \pm 4.4$ & $70.00^{\mathrm{b}} \pm 2.9$ & $85.0^{\mathrm{b}} \pm 5.0$ & $25.00^{\mathrm{c}} \pm 5.8$ & $76.7^{\mathrm{b}} \pm 6.0$ \\
\hline Naringin & $86.67^{\mathrm{a}} \pm 1.7$ & $98.3^{\mathrm{a}} \pm 1.7$ & $60.00^{\mathrm{bc}} \pm 5.8$ & $71.7^{\mathrm{b}} \pm 14.2$ & $55.00^{\mathrm{b}} \pm 10.4$ & $75.00^{\mathrm{b}} \pm 5.8$ \\
\hline Rutin hydrate & $93.33^{\mathrm{a}} \pm 3.3$ & $98.3^{\mathrm{a}} \pm 1.7$ & $55.0^{\mathrm{c}} \pm 5.8$ & $80.0^{\mathrm{b}} \pm 5.8$ & $28.3^{\mathrm{c}} \pm 3.3$ & $76.7 .0^{\mathrm{b}} \pm 18.33$ \\
\hline Imidacloprid & $88.33^{\mathrm{ab}} \pm 1.7$ & $100.0^{\mathrm{a}} \pm 0.0$ & $88.3^{\mathrm{a}} \pm 1.7$ & $100^{\mathrm{a}} \pm 0.0$ & $88.33^{\mathrm{a}} \pm 1.7$ & $100.00^{\mathrm{a}} \pm 0.0$ \\
\hline Water + DMSO & $0.0^{\mathrm{c}} \pm 0.0$ & $3.3^{\mathrm{b}} \pm 1.7$ & $0.0^{\mathrm{d}} \pm 0.0$ & $3.3^{\mathrm{c}} \pm 1.7$ & $0.0^{\mathrm{d}} \pm 0.0$ & $3.3^{\mathrm{c}} \pm 1.7$ \\
\hline (F-value, df) & $(106.31,10)$ & $(58.56,10)$ & $(119.86,10)$ & $(18.60,10)$ & $(55.83,10)$ & $(21.08,10)$ \\
\hline Significance & $P<0.0001$ & $P<0.0001$ & $P<0.0001$ & $P<0.0001$ & $P<0.0001$ & $P<0.0001$ \\
\hline
\end{tabular}

Data were arcsine-transformed before subjected to ANOVA. Means within the same column that have the same letters are not significantly different $(\mathrm{P} \geq 0.05)$ using Least Significant Differences LSD.

Table 2. Percentage mortality of apterous adults of woolly apple aphid (WAA), Eriosoma lanigerum, subjected to different flavonoids at concentrations of $10,000 \mathrm{ppm}, 1000 \mathrm{ppm}$ and $100 \mathrm{ppm}$

\begin{tabular}{|c|c|c|c|c|c|c|}
\hline \multirow[t]{3}{*}{$\underline{\text { Flavonoid }}$} & \multicolumn{6}{|c|}{ Percentage of WAA adults mortality $\pm \mathrm{SE}$} \\
\hline & \multicolumn{2}{|c|}{10,000 ppm } & \multicolumn{2}{|c|}{1000 ppm } & \multicolumn{2}{|c|}{100 ppm } \\
\hline & $\underline{24 \mathrm{~h}}$ & $\underline{72 \mathrm{~h}}$ & $\underline{24 \mathrm{~h}}$ & $\underline{72 \mathrm{~h}}$ & $\underline{24 \mathrm{~h}}$ & $\underline{72 \mathrm{~h}}$ \\
\hline Quercetin dihydrate & $63.3^{b} \pm 6.7$ & $96.67^{\mathrm{a}} \pm 3.3$ & $43.33^{c} \pm 3.3$ & $86.67^{\mathrm{b}} \pm 3.3$ & $36.7^{\mathrm{b}} \pm 3.3$ & $76.7^{b} \pm 3.3$ \\
\hline Naringin & $53.3^{\mathrm{b}} \pm 12.0$ & $93.33^{a} \pm 3.3$ & $46.67^{\mathrm{c}} \pm 3.3$ & $80.00^{\mathrm{b}} \pm 5.8$ & $43.3^{b} \pm 6.6$ & $73.3^{b} \pm 4.0$ \\
\hline Rutin hydrate & $66.7^{\mathrm{b}} \pm 13.3$ & $96.67^{\mathrm{a}} \pm 3.3$ & $56.67^{\mathrm{b}} \pm 3.3$ & $96.67^{\mathrm{a}} \pm 3.3$ & $36.7^{b} \pm 3.3$ & $76.7^{b} \pm 3.3$ \\
\hline Imidacloprid & $90.0^{\mathrm{a}} \pm 0.0$ & $100.0^{\mathrm{a}} \pm 0.0$ & $90.00^{\mathrm{a}} \pm 0.0$ & $100.0^{\mathrm{a}} \pm 0.0$ & $90.0^{\mathrm{a}} \pm 0.0$ & $100.0^{\mathrm{a}} \pm 0.0$ \\
\hline Water + DMSO & $0.0^{\mathrm{c}} \pm 0.0$ & $10.0^{\mathrm{b}} \pm 0.0$ & $0.0^{\mathrm{d}} \pm 0.0$ & $10.0^{\mathrm{c}} \pm 0.0$ & $0.0^{\mathrm{c}} \pm 0.0$ & $10.0^{\mathrm{c}} \pm 0.0$ \\
\hline (F-value, df) & $(27.66,10)$ & $(41.17,10)$ & $(282.29,10)$ & $(62.73,10)$ & $(135.90,10)$ & $(275.29,10)$ \\
\hline Significance & $P<0.0001$ & $P<0.0001$ & $P<0.0001$ & $P<0.0001$ & $P<0.0001$ & $P<0.0001$ \\
\hline
\end{tabular}

Data were arcsine-transformed before subjected to ANOVA. Means within the same column that have the same letters are not significantly different $(\mathrm{P} \geq 0.05)$ using Least Significant Differences LSD. 


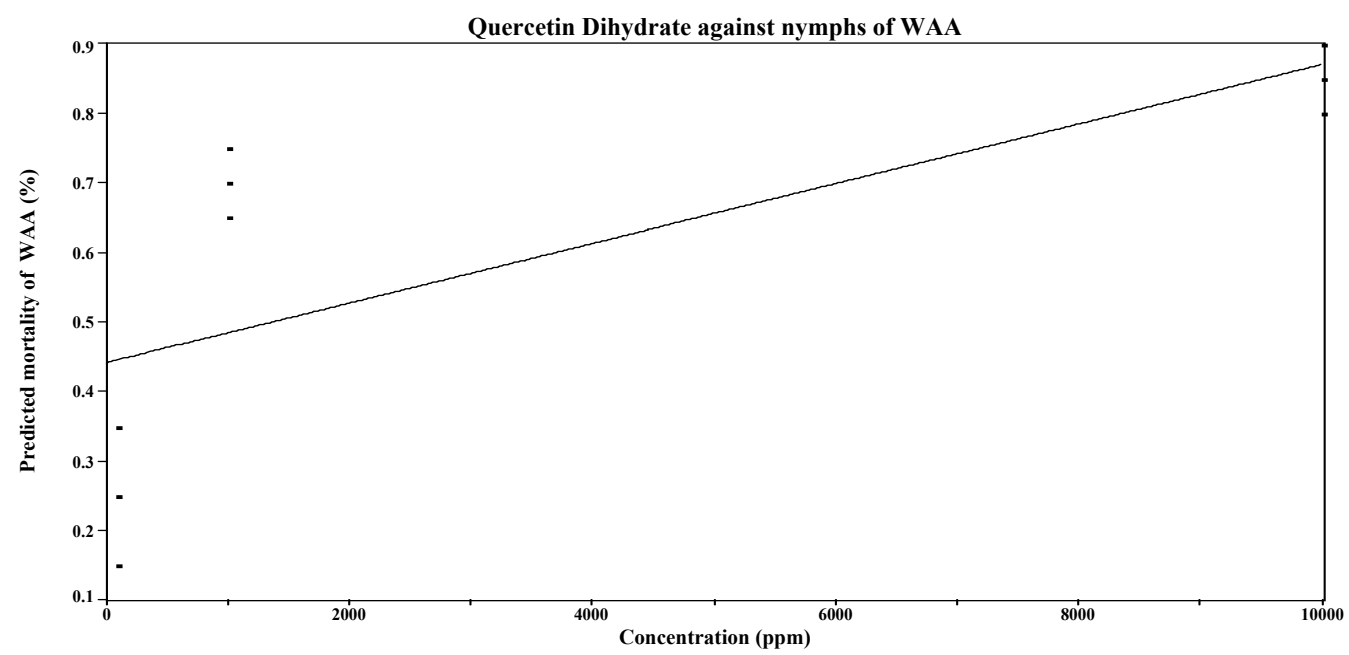

Figure 1. Curve fitting of predicted mortality of woolly appleaphid nymphs exposed to quercetin dihydrate. $y=b+x, \mathrm{r}^{2}$ Coef Det $=0.5354317732, \mathrm{a}=0.441666667, \mathrm{~b}=4.27928 \mathrm{e}-05(\mathrm{P}>|\mathrm{t}|=0.02503)$

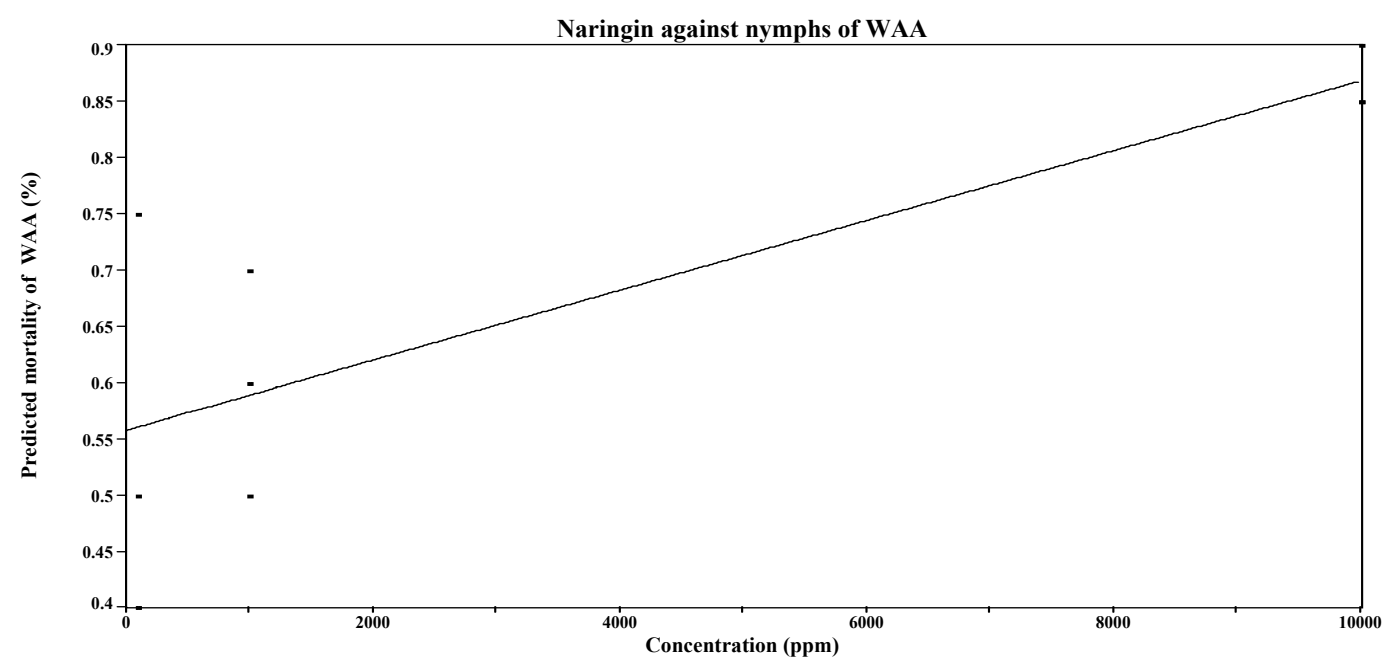

Figure 2. Curve fitting of predicted mortality of woolly apple aphid nymphs exposed to naringin. $y=b+x, \mathrm{r}^{2}$ Coef Det $=0.6645536795, \mathrm{a}=0.557407407, \mathrm{~b}=3.1031 \mathrm{e}-05(\mathrm{P}>|\mathrm{t}|=0.00742)$

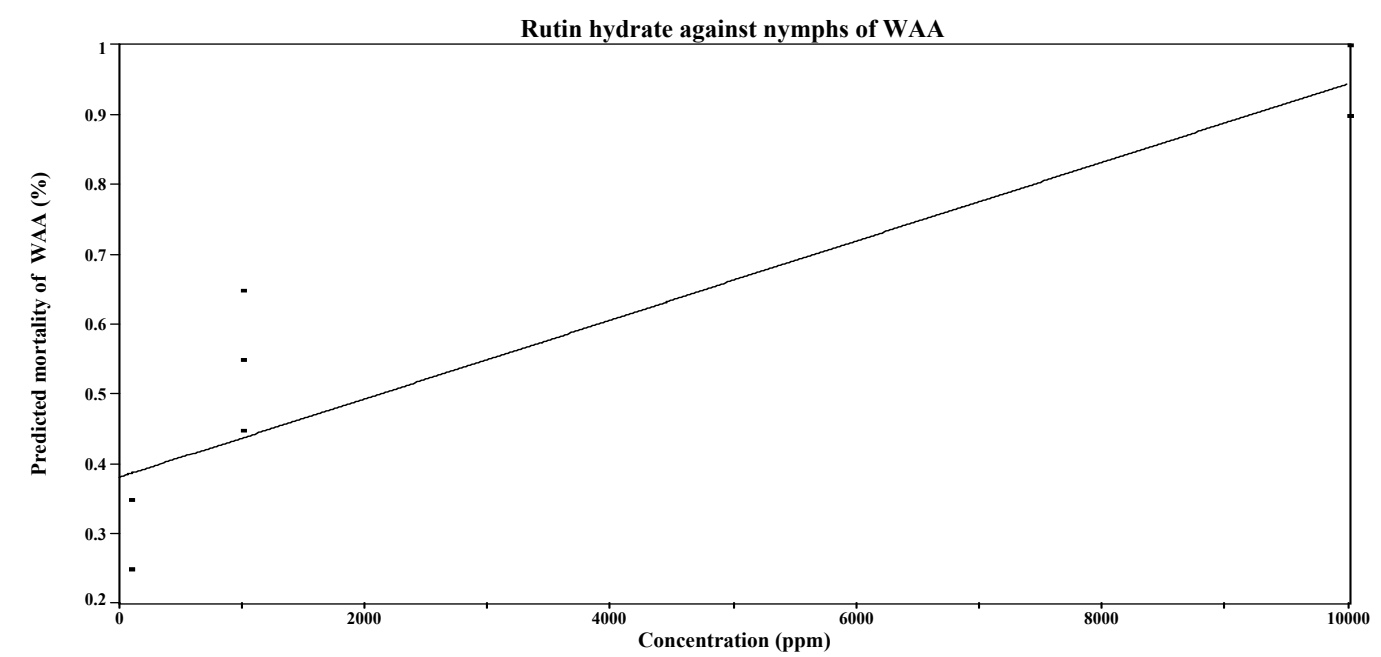

Figure 3. Curve fitting of predicted mortality of woolly apple aphid nymphs exposed to rutin hydrate. $y=b+x, \mathrm{r}^{2}$ Coef Det $=0.8459871661, \mathrm{a}=0.380555556, \mathrm{~b}=5.63063 \mathrm{e}-05(\mathrm{P}>|\mathrm{t}|=0.00044)$ 


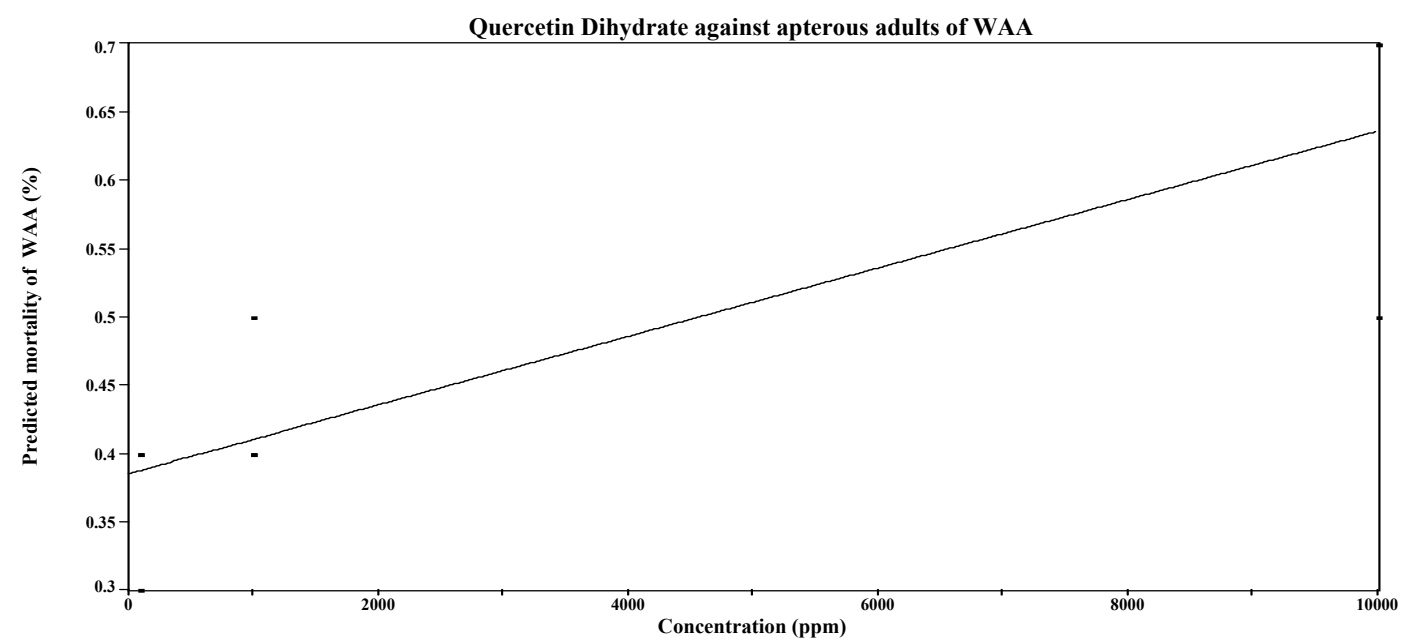

Figure 4. Curve fitting of predicted mortality of apterous adults of woolly apple aphid exposed to quercetin dihydrate. $y=b+x, \mathrm{r}^{2}$ Coef Det $=0.7239382239, \mathrm{a}=0.385185185, \mathrm{~b}=2.5025 \mathrm{e}-05(\mathrm{P}>|\mathrm{t}|=0.00364)$

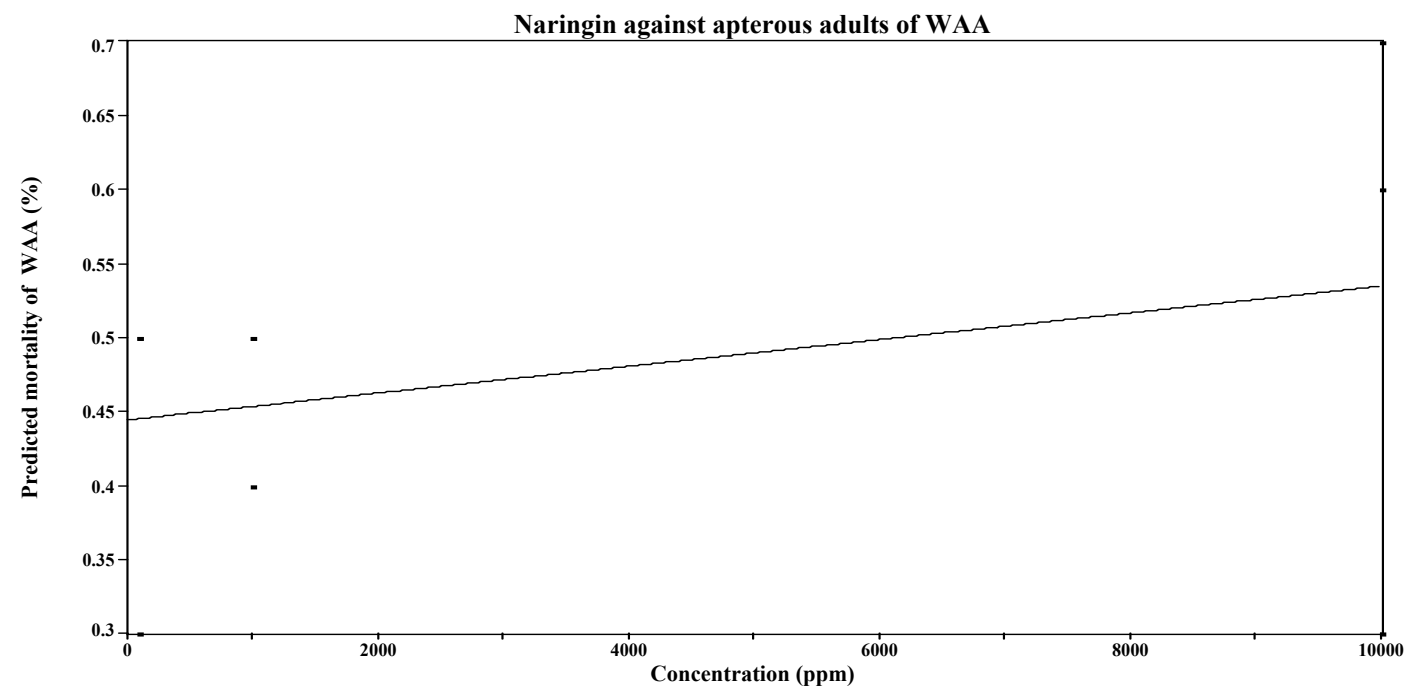

Figure 5. Curve fitting of predicted mortality of apterous adults of woolly apple aphid exposed to naringin. $y=b+x, \mathrm{r}^{2}$ Coef Det $=0.1076650421, \mathrm{a}=0.444444444, \mathrm{~b}=9.00901 \mathrm{e}-06(\mathrm{P}>|\mathrm{t}|=0.38866)$

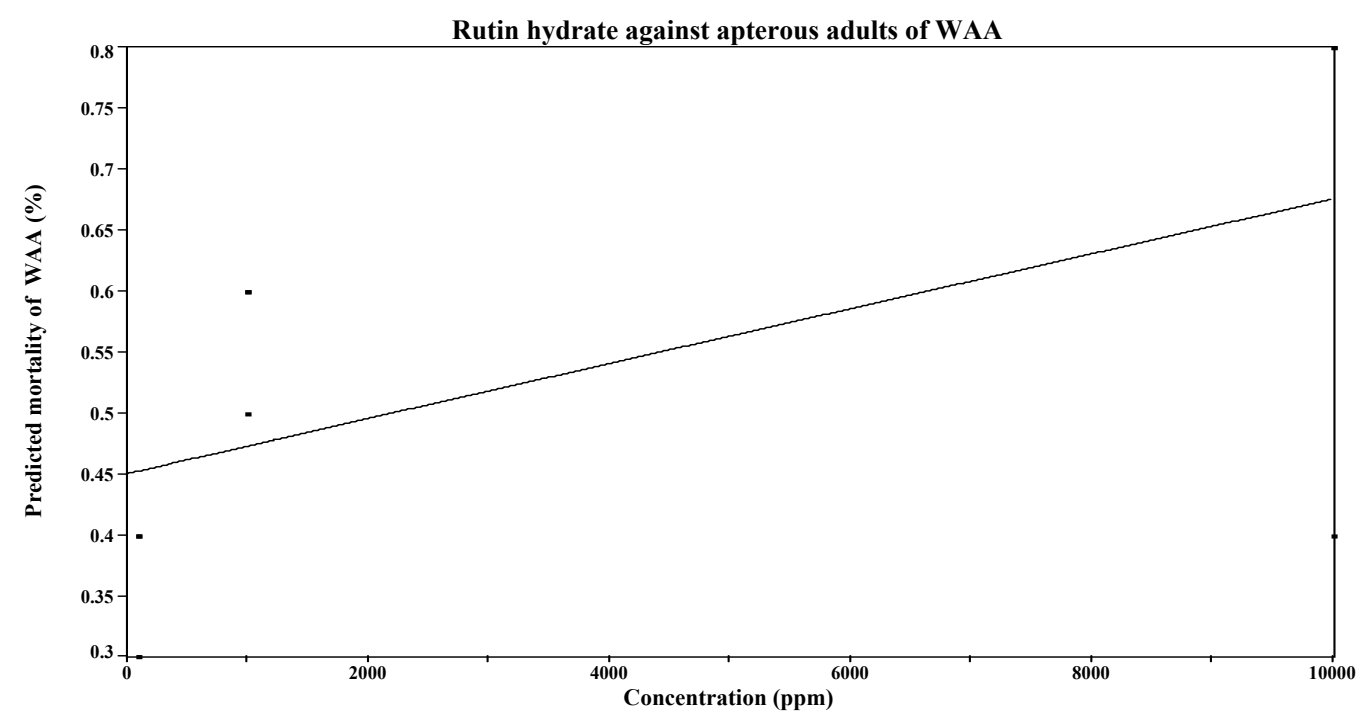

Figure 6. Curve fitting of predicted mortality of apterous adults of woolly apple aphid exposed to rutin hydrate. $y=b+x, \mathrm{r}^{2}$ Coef Det $=0.3508316008, \mathrm{a}=0.450000000, \mathrm{~b}=2.25225 \mathrm{e}-05(\mathrm{P}>|\mathrm{t}|=0.09285)$ 


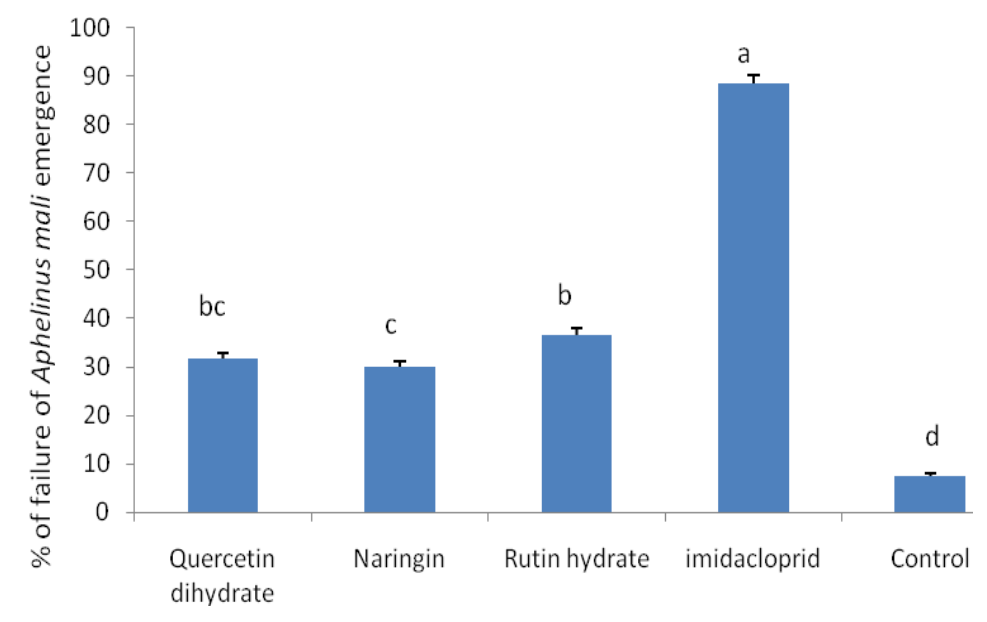

Figure 7. Percentage of failure of Aphelinus mali emergence from mummified WAA aphids 